\title{
How Much Digital Rectal Examination is Valuable for the Decision of Biopsy in Patients with PSA $\leq 4 \mathrm{ng} / \mathrm{ml}$ ? Dijital Rektal Muayene PSA $\leq 4 \mathrm{ng} / \mathrm{ml}$ Olan Hastalarda Biyopsi Kararı Vermede Ne Kadar Önemli?
}

\author{
Özgü Aydoğdu MD, İbrahim Halil Bozkurt MD, Tarık Yonguç MD, Tansu Değirmenci MD, Salih Polat MD, Bülent Günlüsoy MD, \\ İbrahim Küçüktürkmen MD, Yasin Ceylan MD, Süleyman Minareci MD \\ Bozyaka Education and Research Hospital, Clinic of Urology, Izmir, Turkey
}

\section{Summary}

Objective: In this study we aimed to investigate the importance of digital rectal examination (DRE) for the decision of prostat biopsy with transrectal ultrasound (TRUS) in patients with Prostate specific antigen (PSA) $\leq 4 \mathrm{ng} /$ $\mathrm{ml}$.

Materials and Methods: We retrospectively evaluated the data of 287 patients who underwent prostat biopsy with TRUS between 2009 and 2014 and had DRE findings recorded and PSA value $\leq 4 \mathrm{ng} / \mathrm{ml}$. PSA values, DRE findings, biopsy results and gleason grades were noted.

Results: Mean age of the patients was 61.8 (38-85) years. Mean PSA value was $3.1(0.17-4.0) \mathrm{ng} / \mathrm{ml}$. DRE findings were noted as induration, nodularity, irregularity and stiffness. Prostate cancer was detected $78(27 \%)$ in patients with positive DRE findings according to prostate biopsy results. Of the patients with prostate cancer 32 underwent radical prostatectomy in our clinic. Mean biopsy gleason score was $6.23 \pm 1.2$ mean radical prostatectomy gleason score was $6.1 \pm 0.67$.

Conclusion: DRE is an important parameter and guides clinicians in the decision of biopsy and management of patients with PSA $\leq 4 \mathrm{ng} / \mathrm{ml}$.

Key Words: Prostate specific antigen (PSA), digital rectal examination, prostate cancer
Özet

Amaç: $\mathrm{Bu}$ çalışmada prostat spesifik antijen (PSA) $\leq 4 \mathrm{ng} / \mathrm{ml}$ olan hastalarda transrektal ultrasonografi (TRUSG) eşliğinde prostat biyopsisi kararı vermede dijital rektal muayenenin (DRM) öneminin araştıııması amaçlandı.

Gereç ve Yöntem: Çalışmaya kliniğimizde 2009 ve 2014 tarihleri arasında prostat kanseri şüphesi nedeniyle TRUSG eşliğinde prostat biyopsisi yapılan, kayıtlarına ulaşılabilen, DRM bulgusu olan ve total PSA değeri $\leq 4$ $\mathrm{ng} / \mathrm{ml}$ olan 287 hasta dahil edildi. Tüm hastaların dosyaları retrospektif olarak incelendi. Hastaların demografik özellikleri, PSA değerleri, DRM bulguları, biyopsi sonuçları ve gleason gradeleri not edildi.

Bulgular: Çalışmaya dahil edilen hastaların yaş ortalaması 61,8 (38-85) idi. Ortalama PSA değeri $3,1(0,17-4,0) \mathrm{ng} / \mathrm{ml}$ olarak hesaplandı. DRM bulgusu olarak endürasyon, nodül varlığı, düzensizlik ve sertlik not edildiği izlendi. Şüpheli DRM bulguları nedeniyle TRUSG eşliğinde prostat biyopsisi yapılan hastalardan $78^{\prime}$ inde (\%27) prostat kanseri teşhisi konuldu. Bu hastalardan 32'sine kliniğimizde radikal prostatektomi operasyonu yapıldığı tespit edildi. Hastaların prostat biyopsisi histopatoloji sonuçlarına göre ortalama gleason skoru 6,23 $\pm 1,2$ idi. Radikal prostatektomi ameliyatı olan 32 hastanın patoloji sonuçları incelendiğinde ortalama gleason skoru $6,1 \pm 0,67$ olarak tespit edildi.

Sonuç: PSA $\leq 4 \mathrm{ng} / \mathrm{ml}$ olan hastalarda DRM biyopsi kararı vermede ve tedavinin yönlendirilmesi açısından önemli bir parametre olarak yerini korumakta ve klinisyenlere yol göstermektedir.

Anahtar Kelimeler: Prostat spesifik antijen (PSA), dijital rektal muayene, prostat kanseri 


\section{Introduction}

Prostate cancer is one of most important health problems suffered by the male population. It's considered as the second most common cause of cancer-related death after lung cancer. Prostate cancer is the fifth most common cancer in the world (1). Prostate specific antigen (PSA) is a widely used marker for prostate cancer diagnosis and monitoring. PSA is a prostatespecific marker and not cancer-specific, and so any prostate disease including infection and benign enlargement, as well as cancer can cause PSA levels to rise (2). PSA level of $4.0 \mathrm{ng} / \mathrm{ml}$ was accepted as the threshold value for the diagnosis of prostate cancer at the beginning of 1990. This value is considered as the border for prostate biopsy indication in men with normal digital rectal examination (DRE) $(3,4)$. However, prostate cancer was detected in \%5-20 of patients with PSA level of $4.0 \mathrm{ng} / \mathrm{ml}$ or less $(5,6)$. Prostate cancer was detected in $\% 5-30$ of patients with PSA level of $2.0 \mathrm{ng} / \mathrm{ml}$ or less. Nowadays, there is no clear PSA value for prostate biopsy in guidelines. DRE, transrectal ultrasonography (TRUS) and risk assessment is recommended for biopsy with PSA (7).

In this study, we aimed to investigate the significance of DRE for the decision of biopsy in patients with PSA level of $\leq 4 \mathrm{ng} / \mathrm{ml}$.

\section{Materials and Methods}

We retrospectively analyzed the data of 3781 patients who underwent transrectal prostate biopsy between 2009 and 2014, due to suspicion of prostate cancer. A total of 287 patients with abnormal DRE and PSA level of $\leq 4 \mathrm{ng} / \mathrm{ml}$ were enrolled in the study. Demographic parameters, DRE findings, PSA value, biopsy results and gleason score were noted for all patients. We have categorized the patients into different groups according to their PSA values (in ng/ml: 0-0.9, 1-1.9, 2-2.9, 3-4), clinical stage (in stage: II (T1CN0M0, T2N0M0), III (T3NOM0), and IV (N1 or M1)) and Gleason scores (in GS: 2-6, 7, 8-10). Patient data were collected from computer-based patient record system. Patients who used dutasteride were excluded from the study.

Serum PSA levels were measured using Beckman Hybritech Prostate Specific Antigen (PSA) Kit. Palpable induration, nodularity, irregularity and stifness was accepted as abnormal DRE findings. Prostate volume was measured by TRUS using formula (height $x$ width $x$ length $\times$ 0.52). TRUS-guided systematic 12-core biopsy was performed, and if TRUS revealed any abnormal findings, we were performed additional biopsies from abnormal area. All biopsies were performed using a 6.5 $\mathrm{MHz}$ transrectal ultrasound-guided biopsy probes and 18-gauge needle with automatic biopsy gun. Patients were treated with $500 \mathrm{mg}$ ciprofloxacin twice daily before the biopsy and were recommended to continue for at least 3 days after the biopsy. Rectal enema was administered before biopsy. Transrectal injection was performed with $\% 2,20 \mathrm{ml}$ lidocaine for local anesthesia. Statistical analyses were performed with SPPSS 17.0. Statistical comparisons were performed using independent sample t test and Chi-square test. Statistical significance was set at a $p$ value of $<0.05$.

\section{Results}

Clinical characteristics of 407 patients who underwent prostate biopsy for PSA less than $4 \mathrm{ng} / \mathrm{ml}$ and/or DRE suspicious for cancer, according to PSA value, are shown in Table 1. 287 patients had both abnormal DRE findings and a PSA level of $\leq 4$ $\mathrm{ng} / \mathrm{ml}$. A total of 99 prostate cancers (24.3\%) were detected with prostate biopsy. The cancer detection rate was $8.6 \%$ (2 of 23) and $7.1 \%$ (1 of 14) in patients with PSA value of $0-0.9 \mathrm{ng} /$ $\mathrm{ml}$ and $1.0-1.9 \mathrm{ng} / \mathrm{ml}$, respectively. However, the detection rate of prostate cancer was comparatively high at $19.5 \%$ (17 of 87 ) and $27.9 \%$ (79 of 283) in patients with PSA value of 2.0-2.9 $\mathrm{ng} / \mathrm{ml}$ and $3.0-4.0 \mathrm{ng} / \mathrm{ml}$, respectively. $78.8 \%$ of patients with prostate cancer in biopsy had positive and $21.2 \%$ had negative DRE findings. The proportion of clinical Stage II (T1CN0M0, T2N0M0), III (T3N0M0), and IV (N1 or M1) was 85.8\%, 12.1\%, and $2.1 \%$, respectively. Clinically insignificant prostate cancer was detected in two cases with $5 \%$ or less of one biopsy core. In two patients with PSA value of $0.48 \mathrm{ng} / \mathrm{ml}$ and $0.17 \mathrm{ng} /$ $\mathrm{ml}$, squamous cell carcinoma and undifferentiated carcinoma of prostate was detected, respectively. Distant metastasis was determined in both of these patients by bone scintigraphy. These patients were accepted as stage 4 disease.

Detection rates of prostate cancer relative to positive digital rectal examination at varying prostate specific antigen levels are shown in Table 2. In patients with abnormal DRE findings,

\begin{tabular}{|c|c|c|c|c|c|}
\hline & \multicolumn{4}{|c|}{ PSA (ng/ml) } & \multirow[b]{2}{*}{ Total } \\
\hline & $0.0-0.9$ & $1.0-1.9$ & $2.0-2.9$ & $3.0-4.0$ & \\
\hline Patients (n) & 23 & 14 & 87 & 283 & 407 \\
\hline \multicolumn{6}{|l|}{ Age (yr) } \\
\hline Means & 62.8 & 61.8 & 61.9 & 60.6 & 61.7 \\
\hline Range & $44-85$ & $55-79$ & $48-79$ & $38-83$ & $38-85$ \\
\hline Anormal DRE (n) & 17 & 12 & 60 & 198 & 287 \\
\hline $\begin{array}{l}\text { Prostate cancer } \\
\text { cases (n) DRE+ }\end{array}$ & 2 & 1 & 14 & 61 & 78 \\
\hline $\begin{array}{l}\text { Prostate cancer } \\
\text { cases (n) DRE- }\end{array}$ & 0 & 0 & 3 & 18 & 21 \\
\hline $\begin{array}{l}\text { Total of prostate } \\
\text { cancer cases }(n)\end{array}$ & 2 & 1 & 17 & 79 & 99 \\
\hline Detection rate (\%) & 8.6 & 7.1 & 19.5 & 27.9 & 24.3 \\
\hline \multicolumn{6}{|l|}{ Clinical stage } \\
\hline T1c/T2N0M0 & 0 & 1 & 15 & 69 & 85 \\
\hline T3N0M0 & 0 & 0 & 2 & 10 & 12 \\
\hline $\mathrm{N} 1$ or $\mathrm{M} 1$ & 2 & 0 & 0 & 0 & 2 \\
\hline \multicolumn{6}{|l|}{ Gleason score } \\
\hline $2-6$ & 0 & 0 & 11 & 57 & 68 \\
\hline 7 & 0 & 0 & 4 & 17 & 21 \\
\hline $8-10$ & 0 & 1 & 2 & 5 & 8 \\
\hline Other* & 2 & 0 & 0 & 0 & 2 \\
\hline \multicolumn{6}{|c|}{ DRE: Digital rectal examination, PSA: Prostate spesific antigen } \\
\hline
\end{tabular}


the detection rate was low in patients with PSA level of $<2 \mathrm{ng} /$ $\mathrm{ml}$. The detection rate was $11.8 \%(2$ of 17$), 8.3 \%$ (1 of 12$)$, $23.3 \%(14$ of 60$)$ and $30.8 \%$ (61 of 198) in men with PSA value of $0-0.9 \mathrm{ng} / \mathrm{ml}, 1.0-1.9 \mathrm{ng} / \mathrm{ml}, 2.0-2.9 \mathrm{ng} / \mathrm{ml}$ and $3.0-4.0 \mathrm{ng} /$ $\mathrm{ml}$, respectively.

Statistical analysis of abnormal DRE in the detection of prostate cancer at varying prostate specific antigen levels are shown in Table 3. Overall, an abnormal DRE had $27.1 \%$ positive predictive value (PPV), $82.5 \%$ negative predictive value (NPV), $78.7 \%$ sensitivity and $32.1 \%$ specificity.

\section{Discussion}

Prostate cancer patients are usually asymptomatic unless it is very advanced. Elevation of serum PSA or detection of abnormal DRE findings suggests the possibility of prostate cancer. Prostate needle biopsy is the most commonly used diagnostic method for definitive and differential diagnosis of these patients. Nevertheless, threshold value of PSA for prostate biopsy is still controversial (8). For less than $20 \%$ of patients, DRE is the only indicator for prostate biopsy. Among patients with suspicious DRE and low PSA $(<2 \mathrm{ng} / \mathrm{ml})$, the mean volume of tumors and Gleason score were less than $0.5 \mathrm{cc}$ and 6 , respectively (9). DRE is an inexpensive and simple test, but sensitivity and specificity is relatively low (10). The PPV for DRE ranges from $21 \%$ to $53 \%$ depending on the degree of suspicion for cancer and whether the population studied are referred or screened $(11,12,13)$. DRE and serum PSA are useful first line tests for assessing the risk of prostate cancer $(13,14,15)$.

Some studies on the importance of DRE in patients with PSA

\begin{tabular}{|c|c|c|c|}
\hline PSA (ng/ml) & $\begin{array}{l}\text { DRE Positive } \\
\text { Patients (n) }\end{array}$ & PCa Cases (n) & $\begin{array}{l}\text { Detection } \\
\text { Rate (\%) }\end{array}$ \\
\hline $0-0.9$ & 17 & 2 & 11.8 \\
\hline $1.0-1.9$ & 12 & 1 & 8.3 \\
\hline $2.0-2.9$ & 60 & 14 & 23.3 \\
\hline $3.0-4.0$ & 198 & 61 & 30.8 \\
\hline Total & 287 & 78 & 27.2 \\
\hline
\end{tabular}

Table 3. Statistical analysis of abnormal Digital rectal examination in the detection of prostate cancer at varying prostate specific antigen levels

\begin{tabular}{|l|l|l|l|l|}
\hline & \multicolumn{4}{|l|}{ Diagnostic Parameters } \\
\hline PSA (ng/ml) & PPV & NPV & Sensitivity & Specificity \\
\hline $0-0.9$ & 11.8 & 100 & 100.0 & 28.5 \\
\hline $1.0-1.9$ & 8.3 & 100 & 100.0 & 15.3 \\
\hline $2.0-2.9$ & 23.3 & 88.8 & 82.3 & 34.2 \\
\hline $3.0-4.0$ & 30.8 & 78.8 & 77.2 & 32.8 \\
\hline Total & 27.1 & 82.5 & 78.7 & 32.1 \\
\hline $\begin{array}{l}\text { PCa: Prostate cancer, PPV: Positive predictive value, } \\
\text { NPV: Negative predictive value }\end{array}$ \\
\hline
\end{tabular}

levels of $4.0 \mathrm{ng} / \mathrm{ml}$ or less have been done. In USA, the detection rate of prostate cancer in patients with a PSA level of $4.0 \mathrm{ng} / \mathrm{ml}$ or less and abnormal findings on DRE were found between $10 \%$ and $26 \%(13,16,17)$. In our study, the detection rate of prostate cancer was $24.3 \%$ in parallel to previous studies. Catalona and colleagues reported cancer detection rate was $22 \%$ on 363 men who underwent prostate biopsy with PSA levels between 2.6 and $4.0 \mathrm{ng} / \mathrm{ml}$. $81 \%$ of those prostate cancer patients undergoing surgery demonstrated organ-confined disease. Relatively few cancers (17\%) were clinically insignificant at the time of surgery (18).

Previous studies have demonstrated that the proportion of patients with a Gleason score of 8 to 10 is between $3.3 \%$ and $10.8 \%$ in white Americans and $18.4 \%$ in black Americans with the same findings on DRE and the same PSA level $(16,17)$. In a previous study, the rate of patients with a Gleason score of 8 to 10 on the radical prostatectomy specimen was reported $0 \%$ in Dutchmen with abnormal DRE and/or TRUS and PSA level of less than $4.0 \mathrm{ng} / \mathrm{ml}$ (19). In our study, \%8.1 (8 of 99) of patients had a gleason score between 8 and 10 on biopsy which was similar previous studies. In the present study only one patient had a gleason score between 8 and 10 on radical prostatectomy specimen.

The rate of patients with stage II disease was $87.3 \%, 88.2 \%$, and $100 \%$ in men with prostate cancer and PSA levels of 3.0-4.0 ng/ $\mathrm{ml}, 2-2.9 \mathrm{ng} / \mathrm{ml}$ and $1-1.9 \mathrm{ng} / \mathrm{ml}$, respectively. In our study, the rate of stage II disease in patients with PSA level between 2.0 and $4.0 \mathrm{ng} / \mathrm{ml}$ was significantly lower than patients with PSA levels between 1.0 and $1.9 \mathrm{ng} / \mathrm{ml}(\mathrm{p}<0.05)$. Although this result is statistically significant, it is not correct to evaluate due to the lack of patients with psa level of 1.0-1.9 ng/ml. Stage IV nonadenocarcinoma prostate cancer was observed in two patients with PSA level of less than $0.9 \mathrm{ng} / \mathrm{ml}$. In previous studies organconfined disease was between $84 \%$ and $87.9 \%$ in patients who underwent radical prostatectomy with PSA levels of $4.0 \mathrm{ng} / \mathrm{ml}$ or less $(7,8,9,10)$

In some studies, the detection rate for men with PSA levels of 1.0 to $1.9 \mathrm{ng} / \mathrm{ml}, 2.0$ to $2.9 \mathrm{ng} / \mathrm{ml}$, and 3.0 to $3.9 \mathrm{ng} / \mathrm{ml}$ was $8.6 \%$ to $13.5 \%, 13.4 \%$ to $27.2 \%$, and $25.4 \%$ to $28.7 \%$, respectively. Previous studies have demonstrated that accuracy of the DRE in patients with PSA levels of $4.0 \mathrm{ng} / \mathrm{ml}$ or less increased with an increase in PSA levels $(16,17,19)$. In the present study prostate cancer detection rate in patients with a PSA level of 0 to $0.9 \mathrm{ng} /$ $\mathrm{ml}, 1.0$ to $1.9 \mathrm{ng} / \mathrm{ml}$ and 2.0 to $4.0 \mathrm{ng} / \mathrm{ml}$ were $8.6 \%, 7.1 \%$ and $25.9 \%$, respectively. These rates were similar with previous studies. In our study, the positive predictive value of abnormal DRE findings in patients with PSA levels of $1.0 \mathrm{ng} / \mathrm{mL}$ or less was low at $11.8 \%$; it was $8.0 \%$ in other studies $(13,16)$. Because of the PPV of abnormal DRE findings in patients with a PSA level of less than $2.0 \mathrm{ng} / \mathrm{ml}$ is very low and NPV of abnormal DRE findings is very high, we do not recommend routine biopsy in men with a PSA level of less than $2.0 \mathrm{ng} / \mathrm{ml}$ and without marked abnormal DRE findings.

It is not clear whether to perform biopsy in men with first PSA levels between 2.0 and $4.0 \mathrm{ng} / \mathrm{ml}$ immediately. We think that patient age is the most important points to consider in the decision to perform prostate biopsy to detect prostate cancer. Patients with PSA levels between 2.0 to $4.0 \mathrm{ng} / \mathrm{ml}$ without abnormal DRE findings should perform prostate biopsy at least once if their PSA level is higher than their age reference range. 


\section{Conclusion}

DRE, PSA and patient age are important parameter and guides clinicians in the decision of biopsy and management of patients. Because the detection rate of prostate cancer is high in patients level between $2.0-4.0 \mathrm{ng} / \mathrm{ml}$, even though normal digital rectal examination, prostate biopsy should be performed. However prostate biopsy should not be performed patients with normal DRE findings and PSA levels of less than $2.0 \mathrm{ng} / \mathrm{ml}$.

\section{Conflict of interest: The authors reported no conflict of interest related to this article.}

\section{References}

1. Printz C. Many unknowns in low-risk prostate cancer treatment. Ongoing studies and biomarker research may shed light on best approach. Cancer 2009; 115:4645-4646.

2. Polascik TJ, Oesterling JE, Partin AW. Prostate specific antigen: a decade of discovery - what we have learned and where we are going. J Urol. 1999;162:293-306.

3. Catalona WJ, Smith DS, Ratliff TL, et al. Measurement of prostatespecific antigen in serum as a screening test for prostate cancer. $\mathrm{N}$ Engl J Med 1991;324:1156-1161.

4. Ng TK, Vasilareas D, Mitterdorfer AJ, et al. Prostate cancer detection with digital rectal examination, prostate-specific antigen, transrectal ultrasonography and biopsy in clinical urological practice. BJU Int 2005;95:545-548.

5. Colberg JW, Smith DS, Catalona WJ. Prevalence and pathological extent of prostate cancer in men with prostate specific antigen levels of 2.9 to $4.0 \mathrm{ng} . / \mathrm{ml}$. J Urol 1993;149:507-509.

6. Lodding P, Aus G, Bergdahl S, et al. Characteristics of screening detected prostate cancer in men 50 to 66 years old with 3 to $4 \mathrm{ng}$./ ml. Prostate specific antigen. J Urol 1998;159:899-903.

7. National Collaborating Centre for Cancer. Prostate cancer: diagnosis and treatment. London (UK): National Institute for Health and Care Excellence (NICE), (Clinical guideline; no. 175);2014.

8. Carter HB, Pearson JD. Prostate-specific antigen testing for early diagnosis of prostate cancer: formulation of guidelines. Urology 1999;54:780-786.
9. Schröder FH, van der Maas P, Beemsterboer P, et al. Evaluation of the digital rectal examination as a screening test for prostate cancer. Rotterdam section of the European Randomized Study of Screening for Prostate Cancer. J Natl Cancer Inst 1998;90:1817-1823.

10. Brawer MK. The diagnosis of prostatic carcinoma. Cancer. 1993;71:899-905.

11. Cooner WH, Mosley BR, Rutherford CL, et al. Prostate cancer detection in a clinical urological practice by ultrasonography. J Urol 1990;143:1146-1152.

12. Ellis J, Chetner MP, Preston SD, Brawer MK. Diagnosis of prostatic carcinoma; the yield of serum prostate specific antigen, digital rectal examination, and transrectal ultrasonography. J Urol 1994; 152:1520-1525.

13. Catalona WJ, Richie JP, Ahmann FR, et al. Comparison of digital rectal examination and serum prostate specific antigen in the early detection of prostate cancer: results of a multicenter clinical trial of 6,630 men. J Urol 1994;151:1283-1290.

14. Bangma CH, Kranse R, Blijenberj BG, Schroeder FH. The value of screening tests in the detection of prostate cancer. Part 1. Results of a retrospective evaluation of 1726 men. Urology 1995;46:773-778.

15. Littrup PJ, Kane RA, Mettlin C], et al. Cost-effective prostate cancer detection. Reduction of low yield biopsies. Investigators of the American Cancer Society National Prostate Cancer Detection Project. Cancer 1994; 74:3146-3158.

16. Carvalhal GF, Smith DS, Mager DE, et al. Digital rectal examination for detecting prostate cancer at prostate specific antigen levels of 4 $\mathrm{ng} / \mathrm{ml}$ or less. J Urol 1999;161:835-839.

17. Fowler JE, Bigler SA, Farabaugh $\mathrm{PB}$, et al. Prostate cancer detection in black and white men with abnormal digital rectal examination and prostate specific antigen less than $4 \mathrm{ng} / \mathrm{ml}$. J Urol 2000;164:1961-1913.

18. Catalona WJ, Smith DS, Ornstein DK. Prostate cancer detection in men with serum PSA concentrations of 2.6 to $4.0 \mathrm{ng} / \mathrm{ml}$ and benign prostate examination: enhancement of specificity with free PSA measurements. JAMA 1997;277:1452-1455.

19. Schröder FH, van der Cruijsen-Koeter I, de Koning $H J$, et al. Prostate cancer detection at low prostate specific antigen. J Urol 2000;163:806-812. 